\title{
ANALYSIS OF INSURANCE IN AGRICULTURE OF THE REPUBLIC OF SERBIA IN THE PERIOD 2009-2018. ${ }^{1}$
}

\author{
Mladen Petrović ${ }^{2}$, Vedran Tomić 3 , Robert Radišić ${ }^{4}$, Nikola Ljiljanić ${ }^{5}$
}

\begin{abstract}
The subject of this paper is the analysis of agricultural insurance in the Republic of Serbia, which includes the types of agricultural insurance that exist in Serbian insurance market, the subjects that could be insured, as well as the insurance companies that are active in agricultural insurance at national level. The main goal of paper is to define the basic terms in agricultural insurance and to show the products and procedures in agricultural insurance offered by the insurance companies. Additional goal is to show the level of development and coverage of agricultural insurance in Serbia, as well as to point out the importance of insurance for agricultural development. In paper are used descriptive and deduction method, as well as desk research and descriptive statistics methods. Based on the conducted research, it is concluded that the current state in agricultural insurance in Serbia is quite low, while the main factors influencing this situation are underdeveloped agriculture and the fact that agricultural insurance is not mandatory. Insurance is significantly more represented in the crop than in livestock production.
\end{abstract}

Key words: insurance, agriculture, risk, premium, Serbia.

JEL': G22, Q18, G28

1 The work was created as a result of research within the contract on the implementation and financing of scientific research work in 2020. between the Institute for the Application of Science in Agriculture - Belgrade and the Ministry of Education, Science and Technological Development of the Republic of Serbia, contract number: 451-03-68/2020-14/200045.

2 Mladen Petrović, M.Sc., Junior Researcher, Institute for Science Application in Agriculture, 68b Blvd. despota Stefana, 11000 Belgrade, Serbia, Phone: +381 1127516 22, E-mail: mpetrovic@ipn.bg.ac.rs

3 Vedran Tomić, M.Sc., Research Associate, Institute for Science Application in Agriculture, 68b Blvd. despota Stefana, 11000 Belgrade, Serbia, Phone: +381 1127516 22, E-mail: vtomic@ipn.bg.ac.rs

4 Robert Radišić, B.A., Research Associate, Institute for Science Application in Agriculture, 68b Blvd. despota Stefana, 11000 Belgrade, Serbia, Phone: +381 1127516 22, E-mail: rradisic@ipn.bg.ac.rs

5 Nikola Ljiljanić, M.Sc., Research Associate, Institute for Science Application in Agriculture, 68b Blvd. despota Stefana, 11000 Belgrade, Serbia, Phone: +381 1127516 22, E-mail: nljiljanic@ipn.bg.ac.rs

6 Article info: Review Article, Received: $7^{\text {th }}$ November 2020, Accepted: $28^{\text {th }}$ November 2020. 


\section{Introduction}

The paper discusses the general risks and types of risks that may arise in agriculture, as well as the elements of risk management, with a special focus on insurance as one of the most important instruments for the risk management. In addition, it has been analysed the insurance of agriculture in the Republic of Serbia, as well as the types of insurance in use, subjects that could be insured, as well as the active insurance companies turned to agriculture at national level. There are also presented the subsidies for insurance premiums offered by the Ministry of Agriculture, Forestry and Water Management of the Republic of Serbia (MAFWM). In addition, it is done an analysis of current state of agricultural insurance in Serbia, the share of insured elements in the field of crop and livestock production, as well as the analysis of insurance premiums and paid incurred damages.

Agriculture is one of the most important activities in Serbia, which is evidenced by the following facts: area and structure of agricultural land, share of agricultural GDP in total GDP, as well as the participation of agricultural population in total population. Beside all benefits and advantages that Serbia has in agriculture, there are also many risks that affect agricultural production at national level. Agriculture is one of the most risky branches of economy (Pejanović, 2006; Vasiljević, Tomić, 2016). Despite the risks characteristic for all branches of economy (changes in exchange rates, interest rates, tax policy, etc.), agriculture is characterized by risks specific only for this sector, before all the production risks (production is mainly done at open field/outdoor under the influence of unpredictable external influences), (Marković, 2013; Vasiljević et al., 2019). Therefore, observing the agriculture as a separate sector it is necessary to consider all potential risks and their impact on agriculture. Agricultural insurance is considered as one of the best instruments for risk management in agriculture (Vasiljević et al., 2013; Popović, 2017). The damages that could occur in agriculture in some cases could be huge and lead to the complete destruction of material resources and human labour. Therefore, insurance is one of the most important instruments that can prevent complete damage, so depending on the type of used insurance, certain costs could be additionally covered. Insurance does not contribute to the possibility of reducing the occurrence of the insured event, but to the eliminating the financial loss if the insured event occurs (Meuwissen, 2000; Dorfman, 2007). The main task of insurance in agriculture is the protection of the entire production process, especially the protection of crops and livestock (Rauston et al., 2010). Of course, insurance cannot cover all potential risks. As agricultural production in Serbia is one of the most important economic sectors, it is necessary to conduct various measures in order to preserve 
the sector and enable its further development. Insurance is the one of the most reliable ways to preventively protect the farmers from the effects of different risks. Insurance in Serbian agriculture is present for more than one century, while it has gone through several developmental stages (Ivanović, 2003).

Agricultural insurance is a type of non-life insurance applied to various agricultural items in order to prevent farms' income losses gained in practicing of agricultural production. Basically, agricultural insurance aims to provide financial protection to the farmers (Ostojić, 2007). As instrument, insurance cannot prevent occurrence of harmful event, but it can greatly contribute to reduction of the consequences derived from the negative phenomenon. One of the specificities that occur in agriculture is the fact that disasters (catastrophic events) have not appeared every year. This is a reason why the money that farmers pay for agricultural insurance they mostly considers as an expense, but not as an investment in upcoming future.

\section{Materials and Methods}

Descriptive and deduction method have been used in paper, as well as desk research method and methods of descriptive statistics. Concerning the literature sources, it was used the domestic and foreign scientific and professional literature that target the field of insurance and risk in agriculture, as well as the data from the National Bank of Serbia (NBS) turned to insurance in the sector of agriculture. There have been also consulted certain legal acts and regulations concerning agricultural insurance.

\section{Results with Discussions}

Agricultural insurance in the Republic of Serbia is generally seen as a cost, not as an investment that will secure the future. Agricultural insurance in Serbia functions on a voluntary basis, and possible restrictions arise in the case of receiving certain state subsidies or getting agricultural credit (Kočović et al., 2016). Current situation of insurance in Serbian agriculture could be seen from the (internal) documentation of the NBS in whose jurisdiction is the insurance sector as well. The NBS represents the supervisory body over the performance of insurance activities in Serbia. According to the NBS's data for 2019., there are 20 insurance companies operating in Serbia, where the top 5 companies active at the national insurance market could be shown in Table 1. 
Table 1. Ranking list of the five largest insurance companies in the Republic of Serbia in 2019.

\begin{tabular}{|l|c|c|}
\hline \multicolumn{1}{|c|}{ Insurance company } & Rank & Share (\%) \\
\hline Dunav & 1 & 26.9 \\
\hline Generali & 2 & 22.0 \\
\hline DDOR & 3 & 12.1 \\
\hline Wiener & 4 & 11.4 \\
\hline Triglav & 5 & 6.0 \\
\hline
\end{tabular}

Source: Author's calculation according to NBS, 2020.

Among five largest companies in the field of insurance, four of them perform activities in the area of agricultural insurance (Danube, Generali, DDOR and Triglav). Besides the mentioned companies, 4 additional companies have activities in agricultural insurance in Serbia as well, but their participation is very small. Domestic insurance companies generally have defined offers for two forms of insurance in agriculture. The first form targets crops and fruits, namely insurance of crops (crops, intercrops and small crops), perennial plantations, seedlings (fruit, vines and forests), flowers and ornamental plants, seedlings of vegetables and other crops, insurance of forest crops (willows for weaving, poplars, reeds, etc.). The second form is turned to animal insurance and it covers all domestic and some wild animals.

The crop and fruit insurance covers basic risks (hail, fire, lightning strikes, etc.), as well as some supplementary risks (flood, storm, frost, etc.). In animal insurance, companies are offering insurance for basic risks (accident, death, etc.), and supplementary (diseases, death of pups, etc.).

Agricultural production in Serbia is carried out on about 3.5 million hectares. Contracted insurance services cover some $12 \%$ of mentioned area. Data from the last Census in Serbia (2012.) confirms the existence of around 630 thousand farms, where about $3 \%$ of farms are using the agricultural insurance services (SORS, 2013). The analysis of services that insurance companies offer for agricultural purposes confirms that the most significant risks in crop and livestock production are covered by this offer. Beside, in mentioned insurance offer there is a lack of high quality insurance for drought and income loss.

The development of agricultural insurance services can be analysed through the following indicators: number of insurance cards, total agricultural insurance premiums and subsidized agricultural insurance premiums. 
Table 2. Data on agricultural insurance in the Republic of Serbia (period 2009-2018.)

\begin{tabular}{|c|c|c|c|c|c|c|c|c|c|c|c|c|}
\hline$\stackrel{\infty}{\stackrel{\sim}{\sim}}$ & $\begin{array}{l}\frac{N}{N} \\
\hat{\text { nे }}\end{array}$ & $\begin{array}{l}\text { ते } \\
\text { ते }\end{array}$ & \begin{tabular}{l}
$\stackrel{\infty}{\infty}$ \\
$n$ \\
\multirow{\Xi}{n}{}
\end{tabular} & $\begin{array}{l}\overrightarrow{\widehat{\sigma}} \\
\text { m. }\end{array}$ & $\begin{array}{l}\text { నू } \\
\text { }\end{array}$ & $\begin{array}{l}\stackrel{\infty}{2} \\
\text { } \\
\text { N }\end{array}$ & 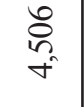 & $\stackrel{\infty}{\stackrel{0}{\sigma}}$ & $\begin{array}{l}\text { d } \\
\text { व. }\end{array}$ & ळె & $\frac{\pi}{\infty}$ & $i n$ \\
\hline 륵 & $\begin{array}{l}\text { o } \\
\text { m. } \\
\text { ᄋ̂ }\end{array}$ & $\begin{array}{l}\stackrel{\text { वे }}{0} \\
\text { i }\end{array}$ & 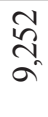 & $\begin{array}{l}\bar{n} \\
\tilde{n} \\
\sim\end{array}$ & $\begin{array}{l}\infty \\
\hat{\sigma} \\
\sigma_{0}\end{array}$ & $\underset{n}{\stackrel{5}{2}}$ & 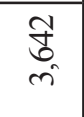 & $\underset{\infty}{\infty}$ & $\frac{\stackrel{P}{I}}{r}$ & 官 & \begin{tabular}{l}
8 \\
\multirow{6}{6}{} \\
6
\end{tabular} & స్ర \\
\hline 룰 & 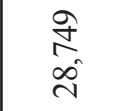 & $\underset{\infty}{\stackrel{\infty}{f}}$ & $\begin{array}{l}8 \\
8 \\
0 \\
0\end{array}$ & సู & $\frac{n}{n}$ & $\stackrel{+}{\infty}$ & $\frac{n}{n}$ & $\hat{\infty}$ & $\frac{R}{}$ & $\begin{array}{l}\infty \\
\infty\end{array}$ & 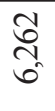 & $\stackrel{\infty}{+}$ \\
\hline$\stackrel{n}{\stackrel{\sim}{\tilde{~}}}$ & $\begin{array}{l}\sqrt{\sigma} \\
\hat{\sim} \\
\tilde{n}\end{array}$ & $\underset{\sigma}{\stackrel{n}{\sigma}}$ & $\frac{\infty}{n}$ & $\hat{8}$ & $\frac{\vec{n}}{m}$ & $\stackrel{ }{ }$ & $\begin{array}{l}\mathbb{J} \\
\curvearrowleft \\
n\end{array}$ & సี & 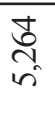 & $\hat{\infty}$ & $\frac{n}{n}$ & $\frac{0}{m}$ \\
\hline ষ্ণ & $\begin{array}{l}\infty \\
\stackrel{\infty}{2} \\
2\end{array}$ & $\underset{-}{\mathbb{O}}$ & $\underset{\infty}{\infty}$ & $\stackrel{n}{\approx}$ & $\begin{array}{l}\underset{\infty}{\hat{\sigma}} \\
\text { }\end{array}$ & $\underset{8}{6}$ & 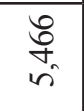 & 寻 & \begin{tabular}{l}
$\frac{n}{\infty}$ \\
\multirow{\sigma}{*}{}
\end{tabular} & $\stackrel{\infty}{\infty}$ & $\begin{array}{l}\underset{J}{J} \\
\dot{\forall}\end{array}$ & તે \\
\hline$\stackrel{\text { 류 }}{\bar{\sim}}$ & 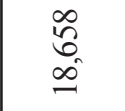 & $\stackrel{n}{n}$ & $\begin{array}{l}n \\
\tilde{b}^{2} \\
\infty\end{array}$ & $\begin{array}{l}\text { वु } \\
\text { i }\end{array}$ & $\frac{\sigma}{\sigma}$ & ?ֶ. & $\begin{array}{l}\hat{6} \\
\underset{+}{*}\end{array}$ & $\stackrel{\leftrightarrow}{q}$ & $\begin{array}{l}\text { \& } \\
\text { ñ }\end{array}$ & ஸ్ర & $\begin{array}{l}\bar{\sigma} \\
\text { సू. } \\
\text { nิ }\end{array}$ & ஓั \\
\hline 굴 & $\begin{array}{l}\vec{\Delta} \\
\dot{\Xi} \\
\pm\end{array}$ & 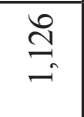 & $\begin{array}{l}\text { 守 } \\
\text { m }\end{array}$ & $\stackrel{\text { N }}{\cong}$ & $\begin{array}{l}\frac{a}{n} \\
\text { in }\end{array}$ & $\stackrel{\ominus}{\nabla}$ & $\begin{array}{l}\text { 今̀ } \\
\text { ñ } \\
\text { ñ }\end{array}$ & $\stackrel{\infty}{\underset{\sim}{\sim}}$ & $\begin{array}{l}\infty \\
\text { ஸू } \\
\text { స్ }\end{array}$ & $\vec{N}$ & $\begin{array}{l}\hat{\text { }} \\
\hat{n} \\
\text { n. }\end{array}$ & రి \\
\hline$\overline{\bar{ন}}$ & $\stackrel{\infty}{\stackrel{+}{n}}=$ & ชे & 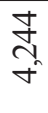 & $\stackrel{2}{\cong}$ & ๙ิ & $\frac{n}{6}$ & 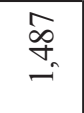 & 워 & $\frac{\vec{m}}{m}$ & $\underset{\forall}{\stackrel{V}{\sigma}}$ & $\begin{array}{l}\text { \& } \\
\text { i }\end{array}$ & $\underline{6}$ \\
\hline 을 & $\stackrel{N}{\cong}$ & $\hat{2}$ & $\frac{1}{\sigma}$ & $\stackrel{\infty}{\infty}$ & \begin{tabular}{l} 
ঠे \\
๙ \\
\multirow{+}{*}{}
\end{tabular} & $\frac{\infty}{a}$ & $\stackrel{\sim}{\sim}$ & $\underset{\sim}{\tilde{N}}$ & $\underset{\sim}{\stackrel{2}{*}}$ & $\underset{n}{\stackrel{2}{n}}$ & \begin{tabular}{l}
$\tilde{N}$ \\
$\stackrel{2}{*}$ \\
\multirow{2}{*}{}
\end{tabular} & 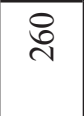 \\
\hline ్ㅗㅇ & $\frac{n}{6}$ & 守 & $\begin{array}{c}\text { సิ } \\
\text { ণ }\end{array}$ & $\stackrel{\infty}{\circ}$ & $\begin{array}{l}\text { ஸे } \\
\text { ஸે }\end{array}$ & $\begin{array}{l}0 \\
n \\
n\end{array}$ & 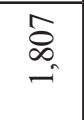 & $\hat{n}$ & $\frac{n}{\hat{\sigma}}$ & $\stackrel{\infty}{n}$ & ठู & లె \\
\hline$\frac{\stackrel{n}{E}}{\frac{0}{0}}$ & 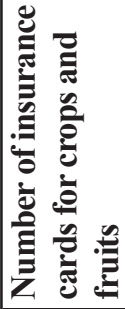 & 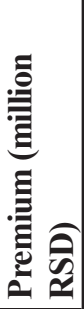 & 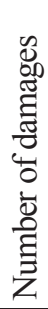 & 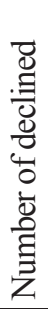 & 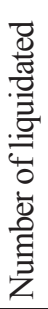 & 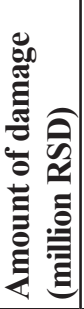 & 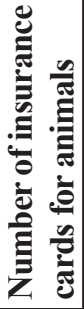 & 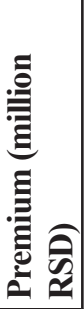 & 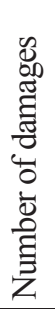 & 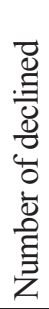 & 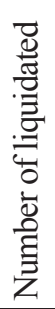 & 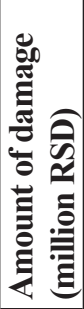 \\
\hline
\end{tabular}

Source: Author`s calculation according to NBS, 2020. 
Graph 1. Dynamics of the number of crop, fruit and animal insurance cards in the Republic of Serbia during 2009-2018.

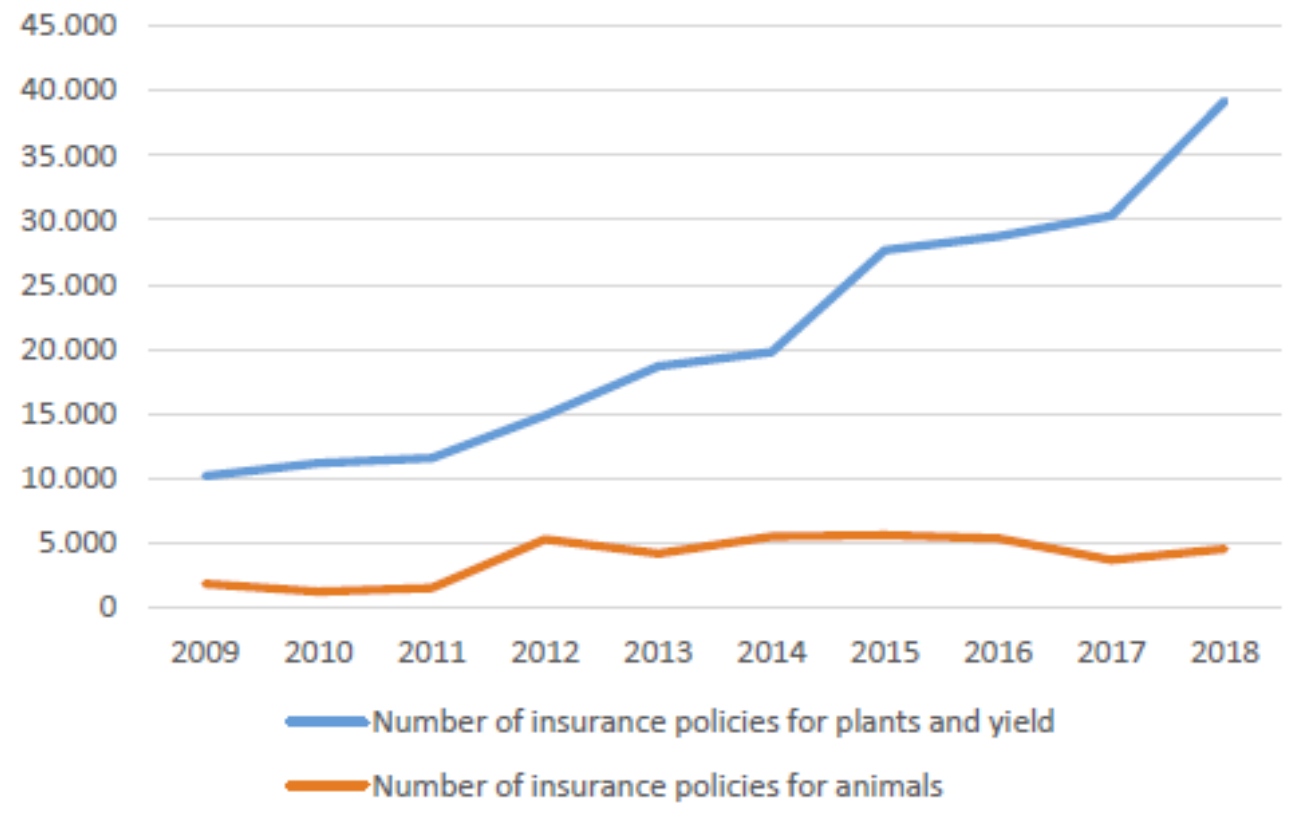

Source: Author`s calculation according to NBS, 2020.

Based on the data presented in the Table 2. and Graph 1., it can be concluded that the number of insurance cards in the crop, fruit and animal insurance has increased significantly during the period 2009-2018. In crop and fruit insurance it increased for 3.8 times, while in animal insurance it increased for 2.5 times.

As was previously said, the number of insurance cards in crop and fruit insurance recorded a constant growth, while the most significant growth occurred in 2015. The largest number of insurance cards was recorded in 2018. $(39,212)$. However, the much higher growth is expected, both as the result of tendencies in business activities of insurance companies, or as required increase in safety and stability of farmers at the national level.

In animal insurance, the number of insurance cards recorded the highest growth in 2012., when it was recorded 5,259 insurance cards (compared to 2011. when there were 1,487 cards). The largest number of animal insurance cards was in 2015. $(5,564)$ and since then it has recorded negative trend. The consequences of the variation in the number of animal insurance cards could be partly explained by the change in the total number of livestock heads in Serbia, which largely depends on the current agricultural policy concerning livestock production. Drop in the number of livestock 
heads has resulted in the number of insured animals. In recent years, there has been a constant decline in livestock heads in Serbia, especially in cattle production (both in number of dairy cattle, as well as in number of cattle used for fattening and breeding).

Graph 2. Number of reported damages for insured crops, fruits and animals in the Republic of Serbia during 2009-2018.

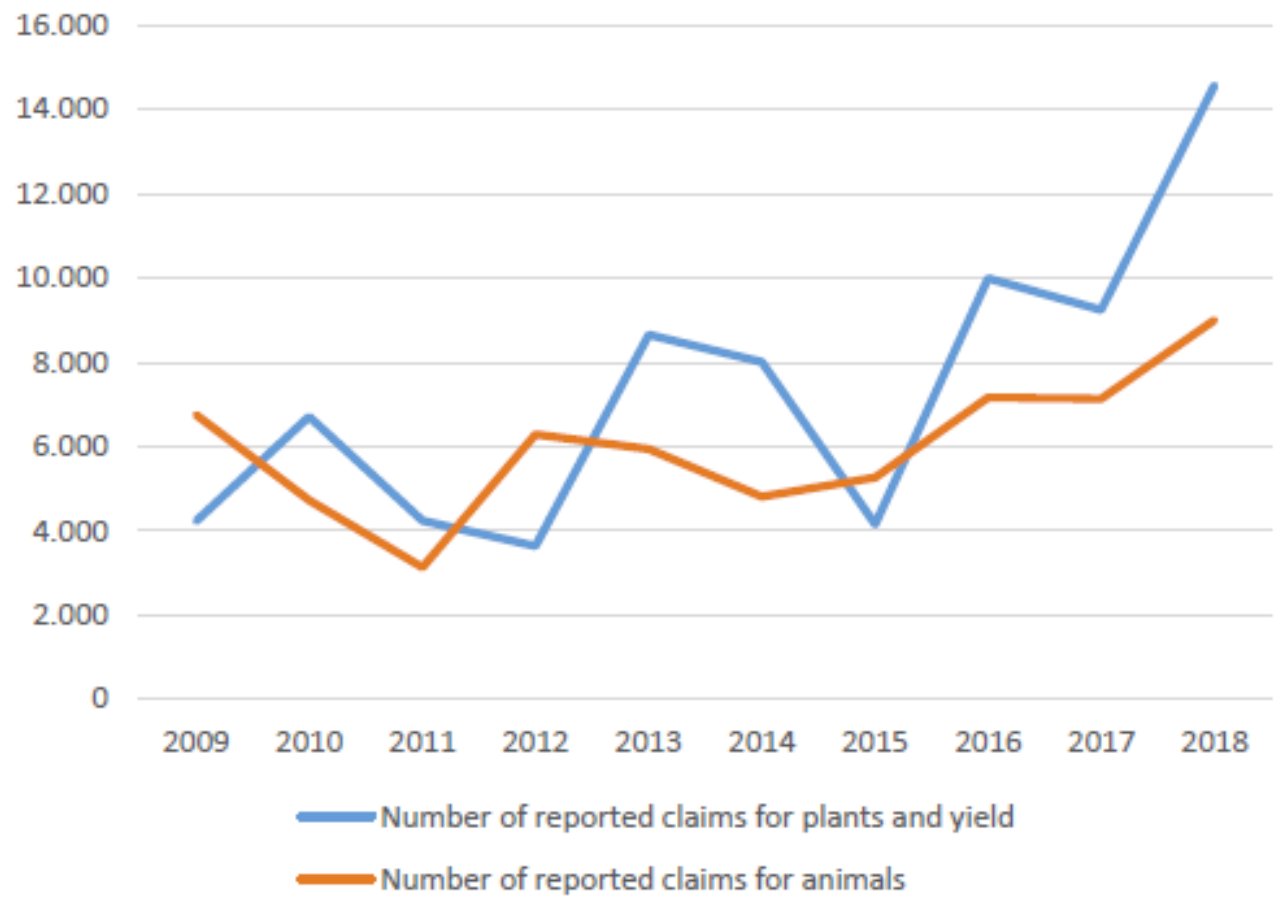

Source: Author`s calculation according to NBS, 2020.

It the Graph 2. it can be seen that the number of reported damages varies more in the crop and fruit insurance, than in animal insurance. The highest number of reported damages in crop and fruit insurance was recorded in 2018. (14,580), while the lowest one was in 2012. $(3,644)$. Number of reported damages in animal insurance was also the highest in 2018. (9,004), while the lowest one was in 2011. $(3,131)$.

Based on data shown in Graph 3., it can be seen how the amounts of premiums and paid off claims in crop and fruit insurance have been changed during the recent decade. These data show that the amounts of claims paid in 2010. and 2018. were higher than the amount of premiums (insurance companies were paid a much more financial assets for damages compared to amount of money they received from the premiums). Also, it can be seen that observed period characterize large variations in amounts of premiums and claims paid in crop and fruit insurance. 
Graph 3. Amounts of premiums and paid off claims in crop and fruit insurance in the Republic of Serbia during 2009-2018.

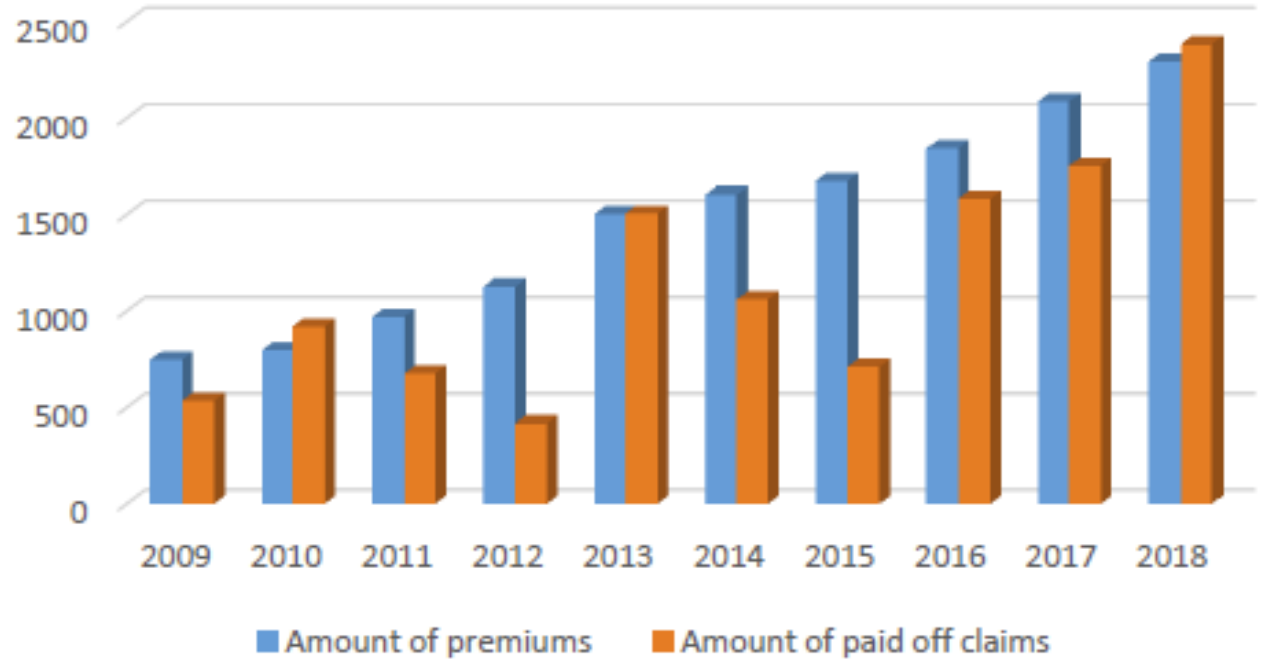

Source: Author`s calculation according to NBS, 2020.

Based on the data shown in Graph 4., it can be seen that there are no similar situation in animal insurance as it occurs in crop and fruit insurance. Within the animal insurance, the sum of paid off claims has not exceeded the amount of premiums in any year within the observed period. It is also come to noticeable variation in presented elements of animal insurance in considered period.

Graph 4. Amounts of premiums and paid off claims in animal insurance in the Republic of Serbia during 2009-2018.

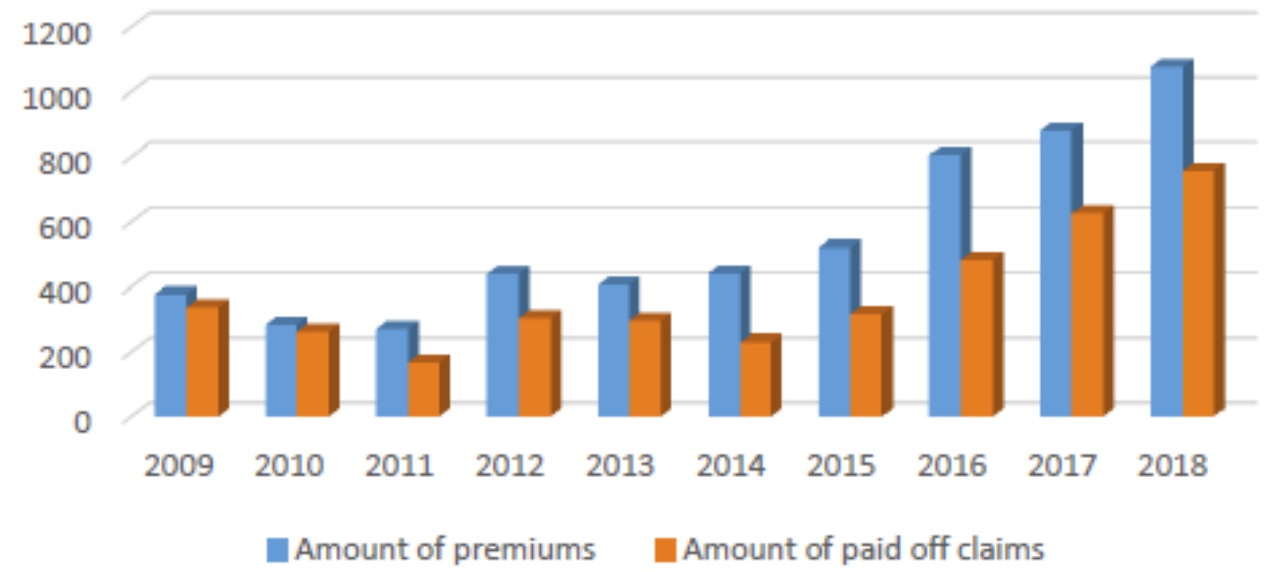

Source: Author`s calculation according to NBS, 2020. 
The Republic of Serbia encourages the insurance in agricultural sector by subsidizing the costs of insurance services (insurance of crops, fruits and livestock). In modern agricultural production, the investments and efforts of farmers can be protected in a meaningful economic way through the insurance services. However, despite the state incentives, there is a weak farmers' response towards the insuring of crop and fruit production, and particularly the livestock production. Lack of Insurance Register in Serbia initiates lack of precise data on the number of insured persons, the size of the insured areas and the number of insured animals. According to some research and estimation, with about $12 \%$ of insured arable land, Serbia is among the last countries in Europe.

Incentives provided by the MAFWM have made it easier for farmers to pay the insurance premium. All registered active farms have the right to use the mentioned incentives. The farm owner is entitled to use the subsidies for insurance in the amount of $40 \%$ of the paid insurance premium without taxes, while in marginal areas (areas of natural or other specific constraints) it could account to $45 \%$ (even more for certain crops). Since 2019. the subsidies have been increased up to $70 \%$ in following five districts of Central and Western Serbia (Zlatiborski, Moravički, Šumadijski, Podunavski and Kolubarski district), where the unwanted weather events are very frequent, causing the great damages. The right to subsidies is exercised by submitting a request with accompanying documentation during the period from July $1^{\text {st }}$ to November $15^{\text {th }}$ of the current year (MAFWM, 2020).

Incentives provided by the MAFWM are up to the following monetary limits:

- for insurance of field crops: 100,000 RSD;

- for insurance of vegetable crops: 500,000 RSD;

- for insurance of fruits, vines and hops: 1,000,000 RSD;

- for insurance of nurseries/young perennial orchards until they entry the yielding: 500,000 RSD;

- for insurance of animals: 2,000,000 RSD;

- the total amount of incentives per farm can be maximally 2,500,000 RSD.

\section{Conclusion}

Based on the analysed literature, conducted research in the field of agricultural insurance and official data of the NBS and the MAFWM certain conclusions can be made towards the characteristics of agricultural insurance in Serbia. By its presence, the insurance market in Serbia has a very long tradition. Insurance in Serbian agriculture is not mandatory. 
Although the number of insured agricultural subjects has been increased in recent years, agricultural insurance in Serbia is still at low level. This could be supported by the data that in 2015. the number of concluded insurance cards for crops and fruits was around 28,000, with a tendency to increase, while in 2018., there were only 39,212 concluded insurance cards. Number of concluded livestock insurance cards has been significantly lower, but it was also growing from year to year. Opposite to small farmers, that are facing several problems, agricultural insurance has been mainly used by the professional and market oriented farmers, as well as the agricultural companies that have large areas under crops and fruits, or large number of livestock and stable products' realization on the market. Based on the internal data of NBS, it can be noticed that increase in number of insurance cards on the market usually occurs in the year after the damage caused by natural disasters such as hail, drought, floods, frost, etc. (e.g. after the great floods in Serbia in May 2014., there was an increase in number of crop and fruit insurance cards, from 19,768 in 2014. to 27,652 in 2015.).

Insufficiently developed agricultural insurance in Serbia is also confirmed by the fact that only around $12 \%$ of agricultural land and $5 \%$ of livestock heads are insured, what is far below the trends that occur in economically developed countries (e.g. in developed EU countries it is insured around $40 \%$ of utilized agricultural area, while in Austria is insured even $90 \%$ of utilized agricultural area).

\section{References}

1. Dorfman, M. S. (2007). Introduction to risk Management and Insurance. Prentice Hall, New Jersey, USA.

2. Ivanović, S. (2003). Upravljanje rizikom i osiguranje. Ekonomski institut, Beograd, Srbija.

3. Kočović, J., Rakonjac Antić, T., Jovović, M. (2016). Mogućnosti razvoja osiguranja poljoprivrede u Srbiji. In: Stanje i perspektiva agroprivrede i sela u Srbiji (Eds.) Stojanović, Ž., Bogdanov, N., Ekonomski fakultet, Beograd, Srbija, pp. 205-224.

4. MAFWM (2020). Data related to incentives in agriculture insurance. Database of the Ministry of Agriculture, Forestry and Water Management of the Republic of Serbia (MAFWM), Belgrade, Serbia, retrieved at: www. minpolj.gov.rs/, 20 $0^{\text {th }}$ October 2020.

5. Marković, T. (2013). Vremenski derivati i upravljanje rizikom u poljoprivredi. Poljoprivredni fakultet, Univerzitet u Novom Sadu, Novi Sad, Srbija. 
6. Meuwissen, M. P. M. (2000). Insurance as a risk management tool for European agriculture. Doctoral thesis, Wageningen University, Wageningen, the Netherlands.

7. NBS (2020). Data related to insurance in Serbia. Database of the National Bank of Serbia (NBS), Belgrade, Serbia, retrieved at: www.nbs.rs/internet/ cirilica/60/60 2/index.html, $20^{\text {th }}$ October 2020.

8. Ostojić, S. (2007). Osiguranje i upravljanje rizicima. Data status, Beograd, Srbija.

9. Pejanović, R. (2006). Rizik i osiguranje u poljoprivredi. Poslovna politika, 35:91100.

10. Popović, Lj. (2017). Model osiguranja useva od rizika suše. Doktorska disertacije, Fakultet tehničkih nauka, Novi Sad, Srbija.

11. Rauston, J. M., Richardson, J. W., Outlaw, J. L., Knapek, G. M. (2010). Does Corp Insurance Reduce the Need For Cash Reserves in Savings Accounts? SAEA Annual Meeting, Orlando, USA, retrieved at: https://ageconsearch.umn. edu/record/56413/, $16^{\text {th }}$ October 2020.

12. SORS (2013). Census of Agriculture 2012. Data base of the Statistical Office of the Republic of Serbia (SORS), Belgrade, Serbia, retrieved at: www.stat.gov.rs/, $10^{\text {th }}$ October 2020.

13. Vasiljević, Z., Kovačević, V., Ralević, N. (2019). Rizici i osiguranje u poljoprivrednom sektoru. Poljoprivredni fakultet, Beograd, Srbija.

14. Vasiljević, Z., Tomić, V. (2016). Upravljanje rizikom poslovanja na poljoprivrednom gazdinstvu i sistem osiguranja u poljoprivredi Srbije. In: Unapređenje finansijskih znanja i evidencije na poljoprivrednim gazdinstvima u Republici Srbiji (Eds.) Subic et al., Institut za ekonomiku poljoprivrede, Beograd, Srbija, pp. 71-94.

15. Vasiljević, Z., Zarić, V., Šević, D. (2013). Insurance in Agriculture of Serbia as Precondition of Risk Minimization. In: Agriculture and Rural Development - Challenges of Transition and Integration Processes (Eds.) Bogdanov, N., Stevanovic, S., University of Belgrade, Faculty of Agriculture, Belgrade, Serbia, pp. 306-316. 